\title{
Permocalculus iagifuensis sp. nov.: A new Miocene gymnocodiacean alga from Papua New Guinea
}

\author{
M.D. SIMMONS \& M.J. JOHNSTON \\ Exploration Technology Branch, BP Research Centre, Chertsey Road, \\ Sunbury-on-Thames, Middlesex, TW16 7LN, United Kingdom.
}

\begin{abstract}
Permocalculus iagifuensis, a new species of gymnocodiacean alga is described from the Miocene of the Darai Limestone Formation of Papua $\mathrm{N}$ ew Guinea. The discovery of this species greatly extends the range of gymnocodiacean algae, which previously had only been confidently recorded from the Permian and Cretaceous. It also suggests an evolutionary link to the Recent genus Galaxaura (order Nemalionales; family Chaetangiaceae), which is the only extant alga bearing a similarity to the Gymnocodiaceae. Alternatively, a closer relationship to the green udoteacean algae (e.g. Halimed $a$ ) is considered. The microfauna and other microflora associated with this new species are briefly described.
\end{abstract}

\section{INTRODUCTION}

The Darai Limestone Formation (Late Oligocene-Middle/Late Miocene) of Papua New Guinea contains abundant and diverse calcareous algae. Coralline rhodophytes are dominant, but Udoteaceae, and more rarely, Dasycladaceae, also occur. During the course of a review of the palaeoecological significance of calcareous algae from the lower $\mathrm{Tf} 1$ larger foraminiferal biozone (cf. Adams, 1984) (Early Miocene = biozones N6-N7 of Blow, 1969), it was noted that gymnocodiacean algae were also present. These were referred to a new species of the genus Permocalculus which is described below.

Elliott (1955) erected the family Gymnocodiaceae, which presently contains only two genera, Gymnocodium and Permocalculus, for the remains of fossil plants similar to the living marine red alga Galaxaura (order Nemaliones; family Chaetangiaceae). These fossil forms are believed to have been erect, branched plants, but are only known from perforate, calcareous segments and fragments. The fossil Gymnocodiaceae are held to be distinct from their Recent counterparts on the basis of greater calcification in the fossil forms and the discontinuous record of similar forms between the Permian, Cretaceous and the Recent. Gymnocodiaceae remain a poorly understood group of calcareous algae. Their peculiar discontinuous stratigraphic range, and the lack of completely analogous extant forms, has inhibited elucidation of their palaeobiology. The record of this new species, the first ever from the Neogene, is important because it points to a more continuous stratigraphic record than previously imagined, and suggests an evolutionary link between fossil calcareous forms and the Recent poorly calcified Galaxaura.
STRATIGRAPHY AND MICROPALAEONTOLOGY. The Darai Limestone Formation (eg. Davies, 1983) crops out across much of the Highlands region of Papua New Guinea. The samples discussed here are from outcrops in the fold belt region south of Tari (see Fig. 1). The Darai Limestone Formation includes several bioclastic limestone types, representing a variety of environments from back-reef, through a number of reef and peri-reefal sub-environments, to fore-reef. Reefs are

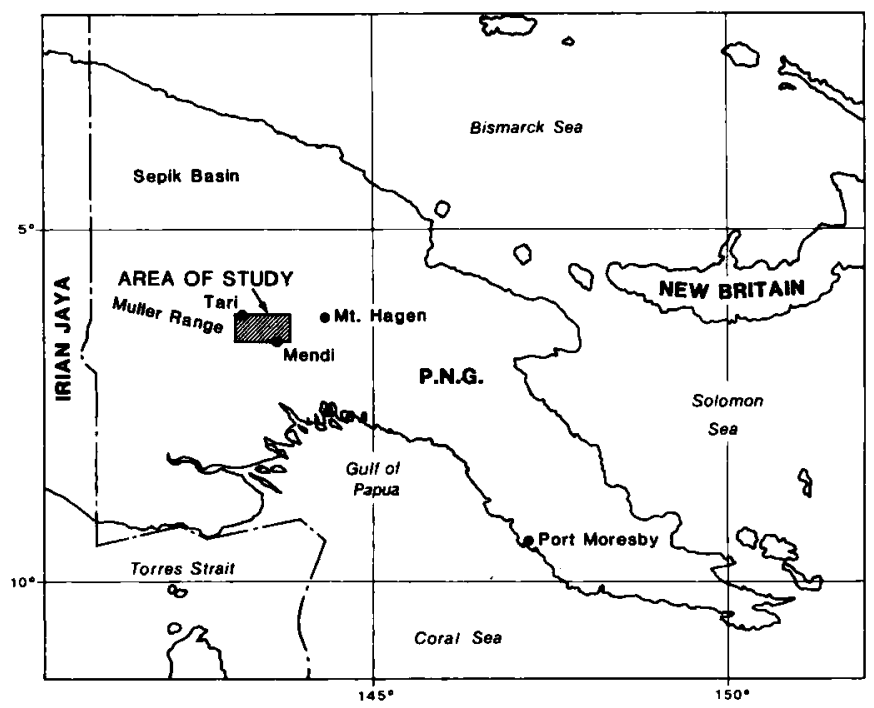

Fig. 1 Location map showing the area from which Permocalculus iagifuensis sp. nov. was recorded. 
dominated by associations of corals and encrusting rhodophytes (e.g.Lthophyllum, Mesophyllum, Archaeolithothamnium), and occasionally bryozoans. Because of extensive rainforest cover, clear exposures of the Darai Limestone Formation are rare, thus it is difficult to visualize the architecture of the carbonate platform. This is further inhibited by extensive thrusting of the formation. In order to reconstruct the nature of the carbonate platform, isolated samples have to be examined in thin-section, and a picture of the platform gradually pieced together. Provisional analysis suggests that a broad east-west trending plat- form area existed with numerous coral-algal bioherms, although more linear reefs also existed, especially fringing the platformal area. An extensive area of fore-reef talus developed on the northern flank passing into more pelagic outer neritic and basinal environments. The Darai platform is thought to be broadly analogous to the Great Barrier Reef (cf. Maxwell, 1968).

The Darai Limestone Formation ranges in age from Late Oligocene to Middle/Late Miocene (see Fig.2 for summary of regional stratigraphy). The samples containing Permocalculus

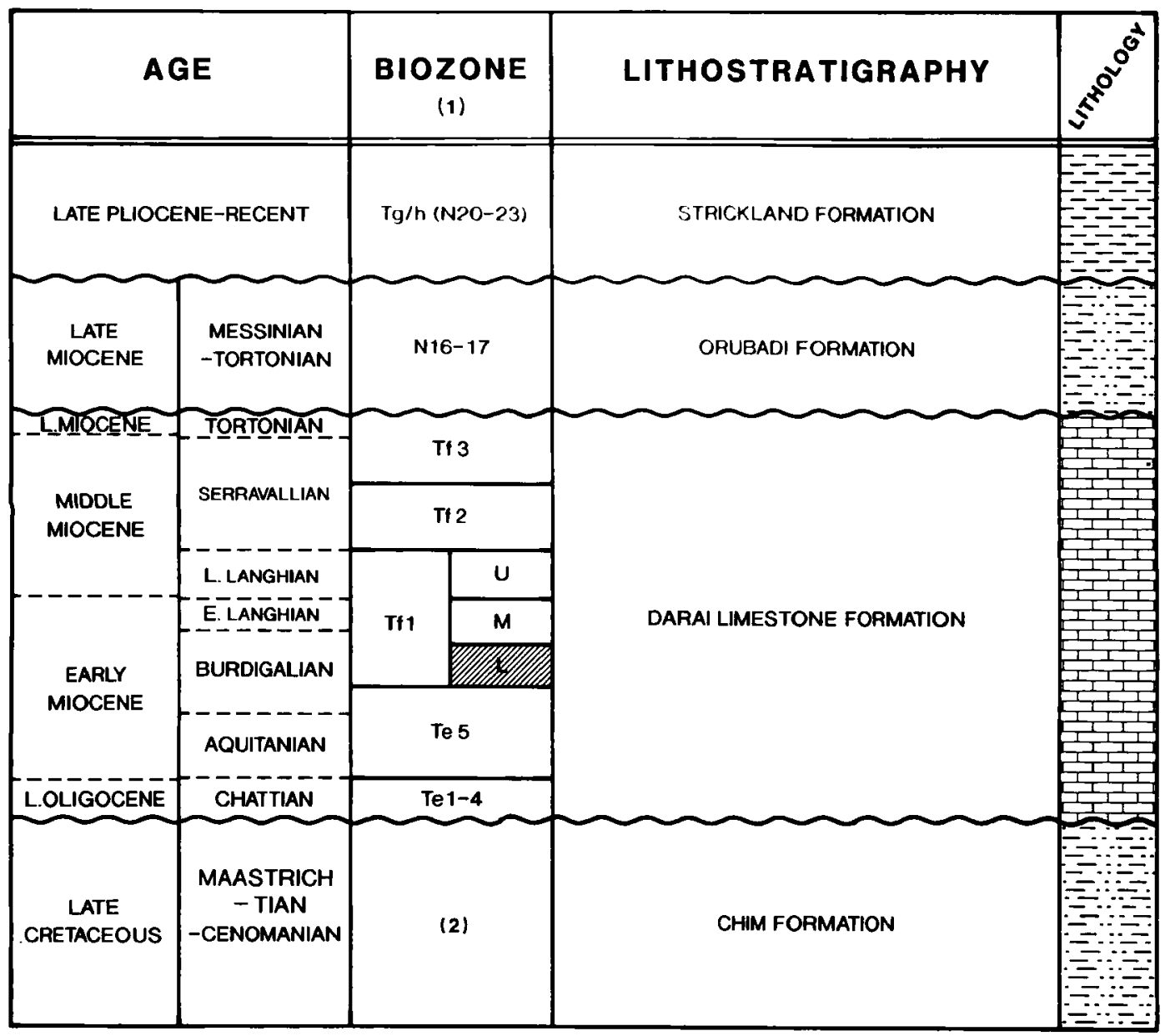

Fig. 2. Summary of the regional stratigraphy (not to scale). The level from which Permocalculus iagifuensis sp. nov. was recorded is highlighted. To the east of the study area the Darai Limestone Formation may be underlain by Paleogene carbonates and sands of the Mendi Group. To the east the Darai Limestone Formation also becomes more plagic in character. Age ranges quoted for formations are variable - they may range considerably (e.g. age of top Chim Formation).

(1): Benthonic foraminiferal biozonation based on that detailed by Adams (1970; 1984). Planktonic foraminiferal biozonation based on that of Blow (1969) modified by Kennett \& Srinivasan (1983).

(1): Zoned by Palynomorphs.

Figs 1-4 Permocalculus iagifuensis sp. nov.

\section{Explanation of Plate 1}

Fig. 1. Longitudinal section of holotype (BM[NH] V.63167), x32.

Fig. B. Longitudinal section of paratype (BM[NH] V.63168), x32.

Fig. C. Enlarged longitudinal section of holotype (BM[NH] V.63167), $x 60$.

Fig. D. Longitudinal section of paratype, $x 32$ (BM[NH] V.63168). Large cavities caused by boring activity. 
1

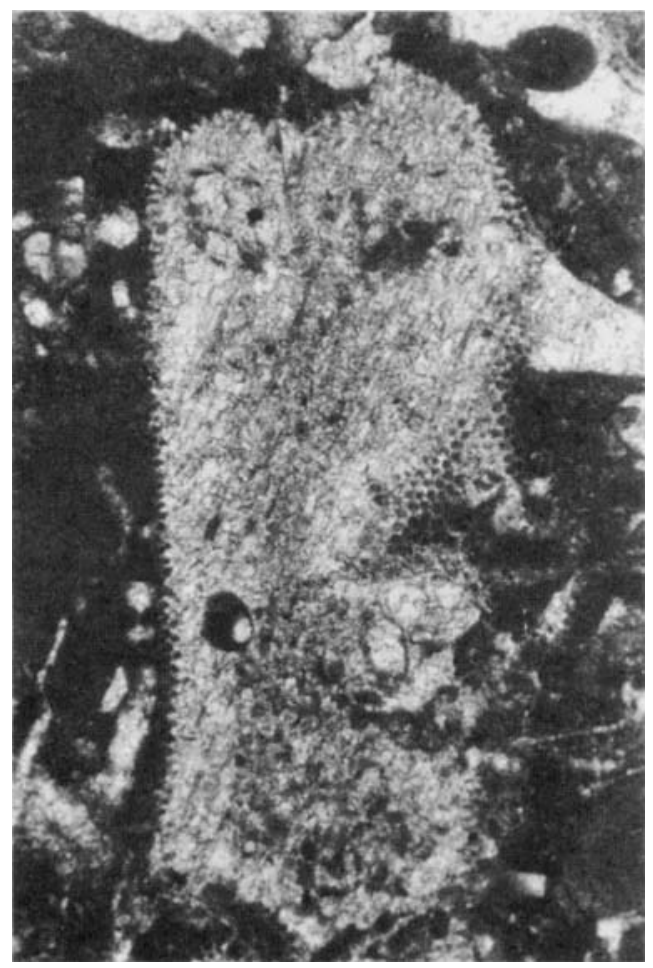

3

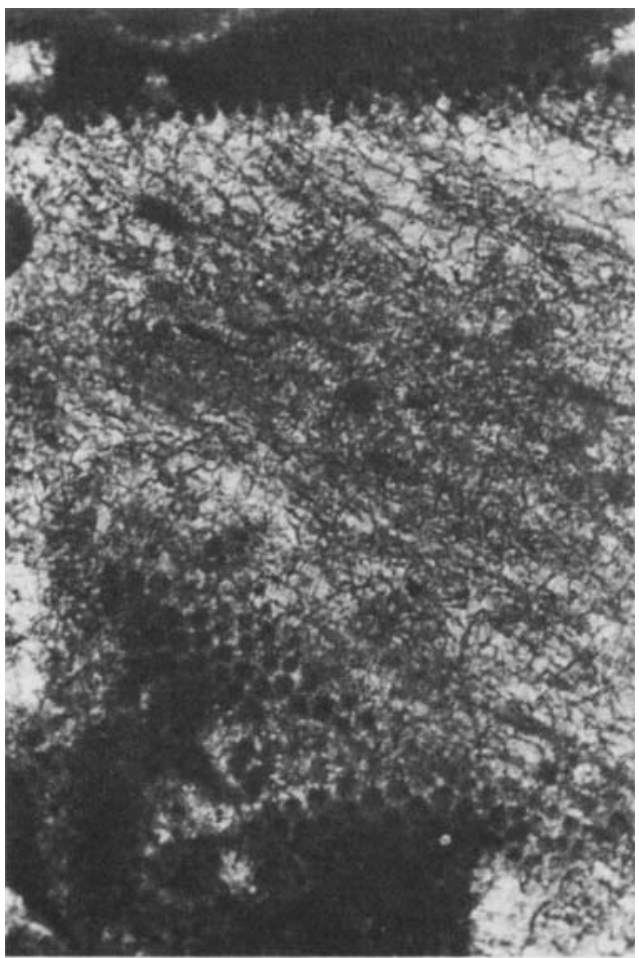

2

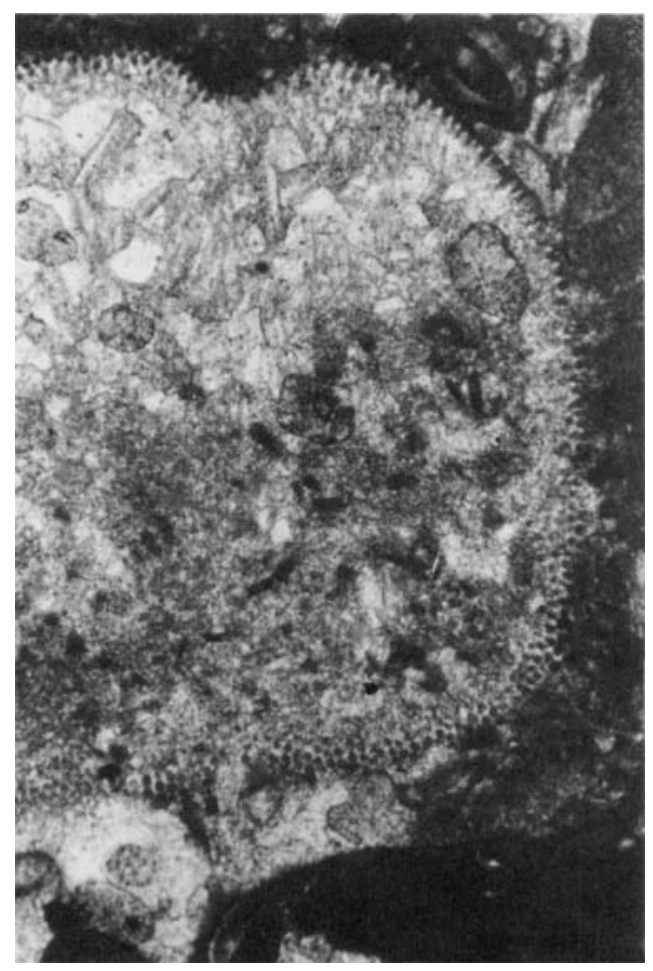

4

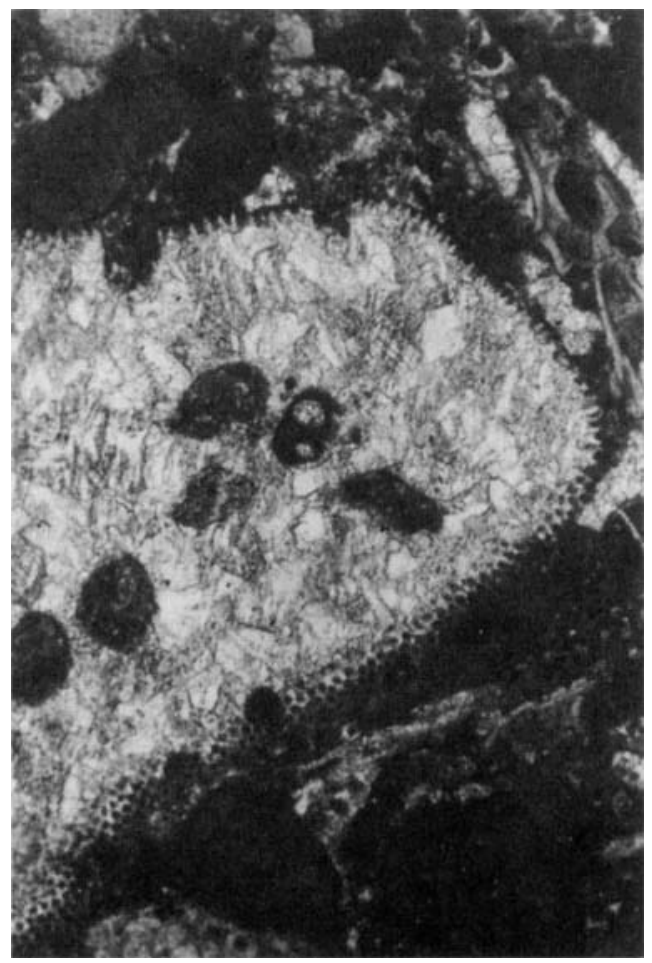


iagifuensis sp. nov., yield a foraminiferal fauna which includes Austrotrillina howchini (Schlumberger), Flosculinella botangensis (Rutten) and Miogypsinoides spp. This fauna suggests the sediments can be assigned to the lower part of the Tf 1 biozone (Adams, 1970; 1984), equivalent to an Early Miocene (Burdigalian) age or global planktonic foraminiferal biozones N6-N7 (Blow, 1969).

As well as the foraminifera mentioned above, the following fauna and flora is also recorded as being associated with Permocalculus iagifuensis sp. nov. : Elphidium sp., miliolids, Sorites sp., Victoriella sp., Miogypsina kotoi Hanzawa (foraminifera); Halimeda sp., Lithopyllum sp., Archaeolithothamnium sp., Lithoporella melobesioides Foslie, Corallina sp., indeterminate rhodophytes (algae); bryozoan debris, coral debris, mollusc debris and echinoderm debris. The microfacies is a poorly sorted bioclastic wackestone - packstone. The microfossil assemblage and sedimentology suggest deposition in shallow water $(<20 \mathrm{mbsl})$, back-reef conditions close to a biohermal buildup.

\section{SYSTEMATIC PALAEONTOLOGY}

Phylum Rhodophyta Wettstein 1901

Class Rhodophyceae Ruprecht 1851

Order Cryptomemiales 1892

Family Gymnocodiaceae Elliott, 1955

Genus Permocalculus Elliott, 1955

(Type Species Gymnocodium fragile Pia, 1937)

Permocalculus iagifuensis sp. nov.

(PI.1, figs 1-4)

Derivation of name. Toponymic, after the lagifu Anticline, a structure in the vicinity of the sample location from where the first specimens of the new species were noted.

Diagnosis. Species of Permocalculus preserved as strongly calcified segments with closely spaced cortical pores typically $0.02 \mathrm{~mm}$ in diameter.

Holotype. Plate 1, figs 1 \& 3. Deposited in the Department of Palaeontology, British Museum (Natural History), reference V.63167.

Paratypes. Plate 1, figs $2 \& 4$. Deposited in the Department of Palaeontology, British Museum, (Natural History), reference V.63168-69.

Type Locality and Horizon. Outcrops of Darai Limestone Formation in the Papuan Fold Belt south of Tari, Papua New Guinea. Lower Tfl biozone, Early Miocene (Burdigalian) (= global planktonic foraminiferal biozones N6-N7 (Blow, 1969)). Description. Species of Permocalculus with segmented thallus. Sectioned segments rectangular to ovoid in outline, probably because of a cylindrical shape. Typical dimensions of segments are length $1.875 \mathrm{~mm}$, width $0.75 \mathrm{~mm}$. However, segments with a length of $4.6 \mathrm{~mm}$ and width of $2.2 \mathrm{~mm}$ have been observed. Calcification is strong in all observed specimens. Pores at the margin of segments have an average diameter of $0.02 \mathrm{~mm}$ (range $0.018-0.023 \mathrm{~mm}$ ) and can be seen to be gently tapering and cup-shaped in cross-section with an average depth of $0.034 \mathrm{~mm}$. Density of pores is about $35-40$ pores per millimeter. Remarks. Permocalculus iagifuensis sp. nov. is the only Neogene species of gymnocodiacean algae known and is difficult to confuse with any other species of Neogene algae. However, the species bears close similarities to Cretaceous and Permian species of Permocalculus. Of the known Cretaceous species, Permocalculus inopinatus Elliott (P1.2, fig.4), often common in Barremian-Aptian platform limestones of the Middle East, is the most similar and can be considered as a homeomorph. This species is preserved as relatively large segments, up to $5 \mathrm{~mm}$ in length and $1.75 \mathrm{~mm}$ in width. Pores have an average diameter of $0.02 \mathrm{~mm}$, and a density of $35-50$ per millimeter (Elliott, 1956). P. inopinatus slightly differs from $P$. iagifuensis in its irregular calcification and variable pore size (0.01-0.03mm reported by Johnson, 1969). The other common Cretaceous species, Permocalculus ampullacea Elliott and Permocalculus irenae Elliott (Pl.2, fig.3), have small pores (typically $0.012 \mathrm{~mm}$ ), with a lower density per millimeter (Elliott 1958, 1959; Johnson, 1969).

Of the Permian species, Permocalculus solidus (Pia) and Permocalculus digitatus Elliott are the most similar to $P$. iagifuensis. From the data given in Elliott (1955), these species have an average pore diameter of $0.02 \mathrm{~mm}$, and the segments of thallus are of a comparable size to those of $P$. iagifuensis. They differ by the variable calcification and the distinctive cylindrical shape of the thallus. It appears that iterative evolution is common within the Gymnocodiaceae, since $P$. solidus, $P$. digitatus, $P$. inopinatus and $P$. iagifuensis can all be considered as homeomorphs.

It is relevant to note here that no suitable Permian or Cretaceous facies exists in the area from which $P$. iagifuensis is recorded, from which the species could have been reworked. Furthermore, reworking of older sediments is not common in the lower Darai Limestone Formation.

Pia (1937) was the first to consider Gymnocodium, the type genus of the Gymnocodiaceae, to be related to the extant genus Galaxaura of the Chaetangiaceae. Earlier, he had considered Gymnocodium to belong to the Codiaceae (=Udoteaceae) (Pia, $1920 ; 1927)$. Elliott (1955) erected the family Gymnocodiaceae and included the genera Gymnocodium and Permocalculus.

\section{Explanation of Plate 2}

Figs 1-2. Longitudinal sections of Halimeda sp. $\times 32$. This species is occasionally found in association with Permocalculus iagifuensis sp. nov. Fig. 3. Permocalculus irenae Elliott $\times 32$. This specimen from Cenomanian sediments of the Oman Mountains is illustrated for comparison with Permocalculus iagifuensis sp. nov.

Fig. 4. Permocalculus inopinatus Elliott $\times 70$. this species from the Early Cretaceous of the Oman Mountains is also illustrated for comparison with Permocalculus iagifuensis sp. nov. The two species can be considered homeomorphs. 

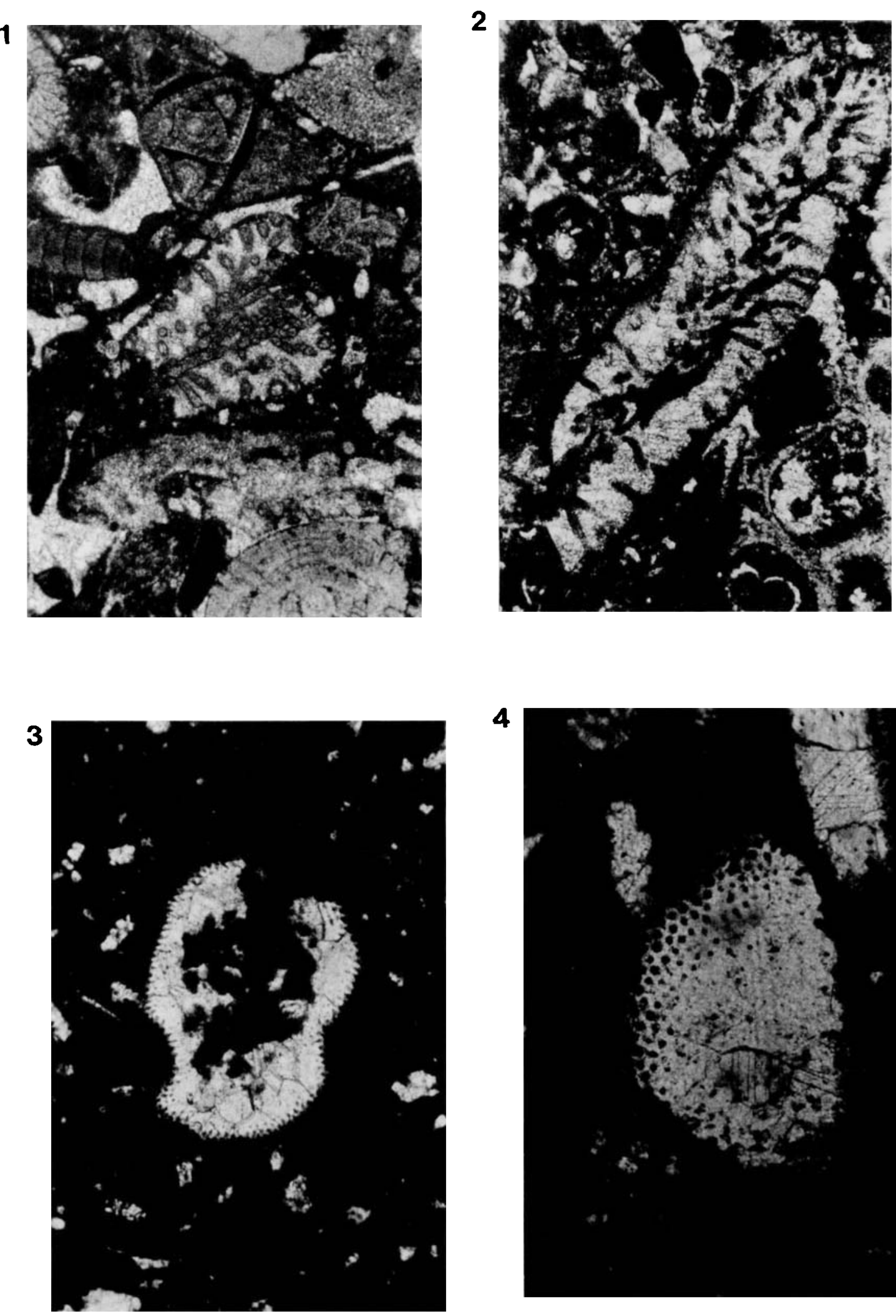

4

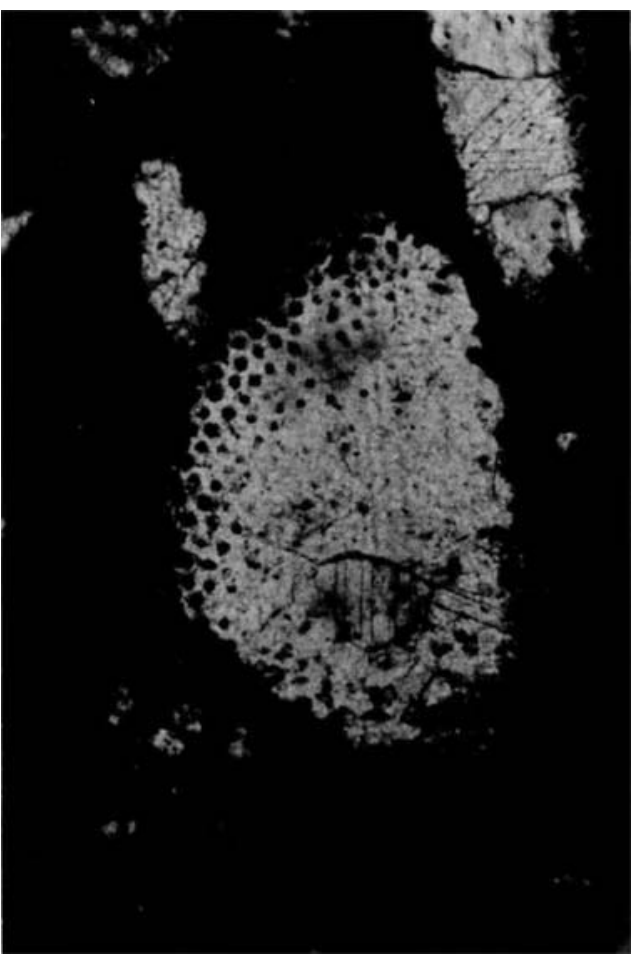


Elliott maintained the view that these genera are related to Galaxaura, but included them in a separate family because of differences in the degree of calcification and the discontinuous record between the Permian and Recent forms. The view that the Gymnocodiaceae are related to Galaxaura has been upheld in subsequent papers (e.g. Elliott, 1961, Johnson, 1969).

Galaxaura is very similar to Gymnocodiaceae such as Permocalculus. Species are typically formed of weakly calcified segments several millimeters in length, united to form a flexible jointed plant with a thallus up to $10 \mathrm{~cm}$ in length. The sporangia of asexual and sexual plants are internal. Although not commonly recorded, the sporangia of Gymnocodiaceae are also internal. This criterion can be used to distinguish the family from the green Udoteaceae in which the sporangia are external. Galaxaura has a pitted, non-calcareous outer skin, beneath which is a calcareous subdermal layer. This can be seen to be penetrated by numerous pores. These have a diameter of $0.01 \mathrm{~mm}$ (Elliott, 1955). Although not identical, this structure is very similar to that seen in species of Gymnocodiaceae.

The discovery of a new species of Permocalculus from Miocene sediments supports the contention that the Gymnocodiaceae and Galaxaura (Chaetangiaceae) are related. Gymnocodiaceae are now confidently known from Permian, Cretaceous and Miocene sediments. It may be that the Chaetangiaceae have exhibited variable calcification, and therefore preservation potential, through time, and that they have in fact experienced a continuous existence from the Permian through to the Recent. The reasons for this variable calcification are unknown, but it appears that records of Gymnocodiaceae correspond to periods of time in which extensive epeiric seas developed. If this model of variable calcification is correct, the term Gymnocodiaceae, which refers only to fossil forms, should be abandoned. Both fossil and extant taxa should be referred to the Chaetangiaceae.

Alternatively it is possible that the Gymnocodiaceae bear a closer relationship to the Udoteaceae than previously thought. The presence of internal sporangia in the Gymnocodiaceae has been cited as a reason for dismissing any suggested relationship to the Udoteaceae. However, the presence of sporangia in the Gymnocodiaceae remains uncertain. There are few illustrations of Gymnocodiaceae where the sporangia can be clearly seen. Moreover, the two groups show similarities. Some illustrations of Gymnocodiaceae show taxa with an internal medullary and cortical arrangement like Udoteaceae (e.g. Permocalculus plumosus Elliott: Elliott, 1955, Pl.2, Fig.2; Gymnocodium bellerophontis (Rothpletz): Johnson, 1961, Pl.29). Also some species of Halimeda (Udoteaceae), and its relatives Arabicodium and Boueina, have a cortex with fine pores as in Permocalculus (e.g. Arabicodium aegagrapiloides Elliott: Johnson, 1969, P1.30, Fig.2). Typical specimens of Halimeda from the Darai Limestone Formation are illustrated for comparative purposes in PI.2, Figs 1 and 2.

The Gymnocodiaceae remain a problematic group requir- ing further detailed studies.

\section{ACKNOWLEDGEMENTS}

The authors wish to thank Dr R.W. Jones and Dr A.A.H. Wonders (BP Research International) and Professor F.T. Banner (British Museum, Natural History) for their comments on an early draft of the manuscript.

This paper is published with permission kindly granted by BP Research International and BP Australia Ltd.

\section{Manuscript received February 1990}

Manuscript accepted October 1990

\section{REFERENCES}

Adams, C.G. 1970. . A reconsideration of the East Indian Letter Classification of the Tertiary. Bull Br. Mus. Nat. Hist. Geology Supplement, 19, 83-137.

Adams, C.G. 1984. Neogene larger foraminifera, evolutionary and geological events in the context of Indo-Pacific datum planes. In: Ikebe and Tsuchi (eds), Pacific Neogene Datum Planes, University of Tokyo Press, 47-67.

Blow, W.H. 1969. Late Middle Eocene to Recent planktonic foraminiferal biostratigraphy. In: Bronnimann, P. and Renz, H.H. (eds), Proceedings of the First International Conference on Planktonic Microfossils, E.J. Brill, 200-421.

Davies, H.L. 1983. Wabag, Papua New Guinea. 1:250,000 Geological Survey Explanatory Notes. Geological Survey of Papua New Guinea, 84pp.

Elliott, G.F. 1955. The Permian calcareous alga Gymnocodium. Micropalaeontology, 1, 83-90.

Elliott, G.F. 1956. Galaxaura (calcareous algae) and similar fossil genera. J. Wash. Acad. Sci., 46, 341-343.

Elliott, G.F. 1958. Algal debris-facies in the Cretaceous of the Middle East. Palaeontology, 1, 254-259.

Elliott, G.F. 1959. New calcareous algae from the Cretaceous of Iraq. Revue Micropaleont., 1, 217-222.

Elliott, G.F. 1961. The sexual organization of Cretaceous Permocalculus (Calcareous Algae). Palaeontology, 4, 82-85.

Johnson, J.H. 1961. Limestone Building Algae and Algal Limestones. Colorado School of Mines, 297pp.

Johnson, J.H. 1969. A review of the Lower Cretaceous algae. Prof. Contr. Colorado Sch. Mines, 6, 180pp.

Kennett, J.P. \& Srinivasan, M.S. 1983. Neogene Planktonic Foraminifera. Hutchison ross, 265pp.

Maxwell, W.G.H. 1968. Atlas of the Great Barrier Reef. Elsevier, 258pp.

Pia, J. 1920. Die Siphoneae Verticillatae vom Karbon bis zur Kreide. Abh. zool.-bot. Ges. Wien, 11, 1-263.

Pia, J. 1927. Thallophyta. In: Hirmer, M. (ed.), Handbuch der Palaeobotanik. Oldenberg, Munich, 1-136.

Pia, J. 1937. Die wichtigsten Kalkalgen des Jungpalaozoikums und ihre geologische Bedeutung. Congr. Av. Etude Strat. Carb. $2 d$ (Heerlen, 1935),, C.R., 2, 765-856. 